\title{
Workplace Inclusion Competence and Employer Engagement ${ }^{1}$
}

I Heidi Enehaug ${ }^{2}$

Senior Researcher, Work Research Institute/Oslo Metropolitan University, Norway

I Øystein Spjelkavik

Senior Researcher, Work Research Institute/Oslo Metropolitan University, Norway

\section{Eivind Falkum}

Research Professor, Work Research Institute/Oslo Metropolitan University, Norway

\section{Kjetil Frøyland}

Research Professor, Work Research Institute/Oslo Metropolitan University, Norway

\begin{abstract}
Existing active labor market policy (ALMP) measures have been unsuccessful in establishing longterm employment for vulnerable groups. This paper contributes to further development of the role of the employer engagement perspective in ALMP. We introduce the term workplace inclusion competence and explore its association to two distinct work-organizational categories: participation- and control-oriented management. We operationalize workplace inclusion competence as inclusion opportunity and inclusion capability. We argue that such competence is dynamic and processual, and find that organizational management-orientation, as well as work pace, employees' developmental opportunities, financial situation and OSH, have an impact on workplace inclusion competence. Survey data among a sample of managers is analyzed regarding workplaces' capabilities and opportunities in work inclusion processes. We present two sets of indexes to measure organizational management-orientation and inclusion skills competence. As such, we contribute to the research field by providing new and more specific concepts with adherent question indexes, and by connecting them to a work-organizational perspective.
\end{abstract}

\section{KEYWORDS}

ALMP / participation / control / work environment / employer engagement / workplace inclusion competence / management

\section{Introduction}

any welfare states have an active labor market policy (ALMP) aimed at helping unemployed vulnerable groups from passive benefits to active work participation. Traditionally, ALMPs have been dominated by supply-side labor preparatory efforts to make vulnerable citizens employable to enhance their ability to get a job (Andersen et al. 2017; NOU 2012:6; van Berkel et al. 2017a).

\footnotetext{
${ }^{1}$ You can find this text and its DOI at https://tidsskrift.dk/njwls/index.

${ }^{2}$ Corresponding author: Heidi.enehaug@oslomet.no.
} 
According to Bredgaard et al. (2015), a consistent rate of $15-25 \%$ of the population of working age are placed outside the labor market. There have been numerous efforts to include citizens with reduced work ability to the labor market. However, it appears to be difficult within the existing ALMP measures both to gain labor market access, and to establish long-term labor market ties, for vulnerable groups (Hardoy et al. 2017; Hauss 2014; Andersen et al. 2017; Bonvin \& Galster, 2010; Ingold \& Stuart, 2015). Andersen et al. (2017) and van Berkel et al. (2017a) argue that ALMPs in the Nordic countries and other European countries are facing major challenges in improving the labor market participation of vulnerable unemployed citizens.

Several studies have shown that various Supported Employment programs increase the probability for a positive inclusion decision (Bonfils et al. 2017; Kinoshita et al. 2013; Nøkleby et al. 2017; Reme et al. 2019). Studies also show that many quickly fall out of externally supported placements or jobs (Nøkleby et al. 2017; Stacy et al. 2017; West et al. 2015). Too much external support may lead to insufficient mobilization of internal assistance in the work organization (Spjelkavik et al. 2020). Lack of knowledge about how to deal with incipient unwanted development can be an obstacle to a successful inclusion process. Other obstacles are inadequate organization of in-house actors who can support, inadequate anchoring of the inclusion process in management and in the work environment, and lack of information to the company about the vulnerable citizen's assistance needs. Referring to such obstacles, Frøyland et al. (2019) argue that PES often lack competence in how to support work inclusion processes at the workplace. As workplaces lack knowledge about the vulnerable unemployed, they ultimately also lack competence in how to handle challenges in work inclusion processes in the work organization. Other contributions support this view on the importance of competencies in the workplaces in work inclusion efforts (Berge \& Falkum 2013; Villotti et al. 2017).

In recent years, the focus on the role of employers in ALMPs has increased, with attention to employers' engagement and social responsibility (Bredgaard 2017; Bjørnshagen \& Ugreninov 2021; Murfitt et al. 2018; van Berkel et al. 2017b). The Norwegian tripartite Agreement on a More Inclusive Working Life (IA-avtalen) and the Danish commitment to «a more inclusive labor market» ('et mere rummeligt arbejdsmarked') are examples. While also Nordic research increasingly focus on the role and experiences of employers (Falkum et al. 2014; Frøyland et al. 2019a; Gustafsson et al. 2013a, $2013 \mathrm{~b}$ ), there is little attention paid to what kind of competence the work organization needs to actually include vulnerable citizens.

In this paper, we suggest that it is necessary to study organizational managementorientation and work environment factors to increase the understanding of the role of the employer engagement in ALMP. Our aim is to present a first draft of an interdisciplinary perspective of workplace inclusion based on theories in the fields of work inclusion, work environment and management, with adherent survey questions and indexes. For this purpose, we present, analyze, and discuss new operationalized concepts and indexes developed theoretically and empirically by using data from a recent Norwegian survey among managers.

We examine two categories of organizational management-orientations (participation-oriented and control-oriented) in relation to workplace inclusion competence (inclusion opportunity and inclusion capability). We further connect workplace inclusion competence and organizational management-orientation to other relevant work 
environmental factors (work pace, employees' developmental opportunities, occupational safety and health, and the financial situation of businesses).

Our major research questions are:

(1) What role do organizational management-orientation play for employer engagement in work inclusion?

(2) What is the association between management-orientation and workplace inclusion competence?

This paper is structured in the following way. First, we present theoretical concepts and assumptions selected from three research fronts: (1) research on the role of employers in ALMP (employer engagement), (2) research on competence in public employment services (inclusion skills competence) and in workplaces (workplace inclusion competence), and (3) research on management and work environment, focusing on control-oriented and participation-oriented management. Secondly, we present data and methods and the analytical approach. Thirdly, we present and discuss the results before the final concluding remarks.

\section{Theoretical perspectives and assumptions}

We use four theoretical/analytical concepts taken from theories of organization and management and theories of work inclusion; employer engagement, inclusion skills competence (ISC), participation, and control. We also introduce a new term, workplace inclusion competence (WIC).

\section{Employer engagement}

According to Bredgaard (2017), some businesses have a high degree of workplace inclusiveness and seem to be differentiated from other businesses by being more motivated to contribute to inclusion - they may also have a more proactive behavior or attitude/a higher degree of employer engagement. Many of them have their own personal experiences that contribute to their involvement, and have brought extra experiences and expertise to the inclusion of people with different types of challenges.

Bredgaard (2017) distinguishes between four types of employer engagement in work inclusion:

(1) The engaged employers (positive attitudes and active efforts)

(2) The dismissive employers (negative attitudes and only make an effort if receiving financial gain)

(3) The skeptical employers (negative attitudes, but make an effort because of institutional pressure)

(4) The passive employers (positively attuned, but make no active effort due to lack of knowledge or perceived relevance)

One of Bredgaards' claims is that efforts to raise the degree of employer participation in work inclusion processes means developing more knowledge about how the rejecting, 
skeptical and passive businesses can become more involved. Furthermore, he states that engaged employers have competence and experiences in work inclusion. In line with Bredgaard, we expect that only a small proportion of Norwegian employers fit this category. With Bredgaard's findings as a starting point, we focus on the role of employers in ALMP by investigating how management orientation and competence development may contribute to workplace inclusion. In doing so, we aim to go beyond employers' attitudes, and examine how identification of different management orientations can help public employment services (PES) differentiate the support towards employers and thereby contribute more proactively to the development of workplace inclusion competence.

\section{Inclusion skills competence (ISC)}

Studies show that many employers have negative perceptions of public employment services (PES) and perceive clients referred by PES as less motivated and trustworthy than other jobseekers (Andersen et al. 2017; Bredgaard 2017; Gustafsson et al. 2013c). In fact, these negative perceptions of both PES and of vulnerable unemployed citizens constitute the main argument behind the need for a different kind of competence development in the support system and additional focus on person-environment fit and job match development (Frøyland \& Spjelkavik 2014; Kirsh 2000). Traditionally, PES mainly focused on supply side measures ('train-place') and client deficits (NOU, 2012:6). With the early 2010s re-orientation towards 'place-train' and demand-side measures, the term inclusion skills competence (ISC) was introduced for practical use in the development of public support services towards vulnerable unemployed citizens. ISC is defined as the frontline worker's skilled use of their social, health, and pedagogical knowledge about the client's interests, challenges, and support needs, combined with knowledge about how the workplace can be utilized in order to develop the job match (Frøyland \& Spjelkavik 2014; Frøyland et al. 2019b; Spjelkavik 2012).

\section{Workplace inclusion competence (WIC)}

In this paper, we shift the attention from ISC in a public service perspective to a workplace perspective by introducing the term workplace inclusion competence (WIC). Inspiration for a shift of attention from ISC to WIC are studies on the intermediate role of PES in matching vulnerable unemployed and employers (Bredgaard \& Halkjær 2016; van Berkel et al. 2017b). We define WIC as the workplaces' customized and contextually adapted approach to the day-to-day follow-up of people with reduced work ability, and knowledge-based accommodation of work tasks in order to meet and balance the needs of the individual and the organization. Thus, the WIC-concept is dynamic; it is embedded in the workplace context and is shaped by the needs of the individual and the organization.

WIC and ISC represents two different, but mostly interdependent, competencies in inclusion, and return to work processes. ISC is regarded as frontline workers' knowledge of clients, workplaces, and inclusion/exclusion processes, while WIC is seen as the workplaces' skilled approach to customized accommodation in such processes. 


\section{Participation, control, and other organizational issues}

Inclusion research referred to above shows a lack of systematic knowledge about specific features of the work organization that makes it more likely to fail or succeed with work inclusion efforts. Therefore, in this paper, we utilize a division between two types of organizational management orientation. In addition, we suppose that people with reduced work ability often has health-related issues, and that factors considered important for work related health are relevant in work inclusion processes, that is, customization of work tasks. We therefore draw attention to research on work environment and health, which increasingly support the importance of work organization for work related health (Karasek 2004; Karasek \& Theorell 1990; Oldham \& Hackman 2010; Parker et al. 2017). Management orientation and work environment is part of the organizational context and may therefore help develop the understanding of work inclusion challenges in the workplace.

The management literature differentiates between principles of organization and management based on participation and control. These different principles of organization and management represent organizational level categories, because they are associated to both the organization of work, and the type of management-employee relations. Some workplaces are organized by principles of standardization, introduction of routines and rule-oriented decision-making processes. Examples are Max Weber's ideal model for the state bureaucracy, Lean Production, goal and result management, as well as balanced goal management (Edwards et al. 2010; Hasle et al. 2012; Rolfsen 2014; Womack \& Jones 1994). Theoretically, we argue that control-oriented management are dominated either by strong external control (often associated with hard HRM) or by strong internal control, through tight psychological and social bonds between employees and management (often associated with soft HRM). Both emphasize the individual relation between employee and manager. This has an impact the organization of work. For example, the more the internal control is connected to the performance system, the stronger elements of control will be found (Kuvaas 2008). For the further elaboration in this paper, we name this type of management orientation 'control-oriented management' (COM).

Other organizational principles, especially found in the Nordic countries, are dominated by participation and co-determination (Berg 1998; Enehaug 2018; Enehaug et al. 2019; Falkum \& Drange 2018; Hvid \& Falkum 2019; Johnsen 2005; Nylehn 2008). Where participation is in use as a management principle, procedures for employee participation in the development of the business, as well as in the design of the workplace and own work, also follow. This implies that participation goes beyond autonomy in own work and significantly extends a pure focus on the employee-manager relationships. Participation in this sense is related to the collective and organizational level through representation (co-determination) and possibilities for broad participatory processes aimed at development and improvement of the organization of work (Berg 1998). This understanding and concept of participation has its theoretical roots in the Norwegian Industrial Democracy Projects (Thorsrud \& Emery 1970), and have since been developed and transferred to Denmark and several other countries (Hasle \& Sørensen 2013; Holt \& Hvid 2014; Hvid 2014; Hvid \& Falkum 2019). In this paper, we have chosen to name this type of management orientation 'participation-oriented management' (POM). Theoretically, we argue that POM operates in line with the basic ideas 
of the Nordic model of work organization characterized by trustful relations between employers and employees (Gardell \& Svensson 1981; Gustavsen 2007, 2011; Kasvio et al. 2012) and where work institutions are based on continuity and adaption (Dølvik et al. 2007).

In addition, a vast amount of work environment research based on the well-established demand-control (-support) -model, developed by Karasek and Theorell (1990; Karasek 1979), has pinpointed factors such as autonomy, social support and developmental opportunities. These factors, among others, seem to have a general impact on health-promoting work environments, in the sense that they contribute to hinder the development of negative stress in individuals. In our analysis, we therefore have included these three variables based on the assumption that they also might affect workplaces' inclusion capabilities and inclusion opportunities. The underlying premise is that health promoting work environments are beneficiary to all employees, including the ones with reduced work ability. In other words, if a work environment has a sufficient balance between demands, control and support, it probably stands a better chance of succeeding in inclusion efforts than control-oriented businesses, because it implies an inclusive and developmental-oriented approach to the work organization and the employees. This line of thought is paramount to our understanding of the POM-index outlined above (and in the method section of this paper).

The COM-oriented businesses are on the other side of the spectrum - in a type of organization where control of the employees' attitudes and actions plays a significant role in the organization of work. In these types of organizations, the control dimension is a dominant feature in the organizing of work, and central management tasks are measuring deviations from individual standards and reporting nonconformities. We assume that COM-based organizations have a poorer starting point for conducting work inclusion processes because the organizational principles guiding work are based more on mistrust than on inclusion. Following that line of thought, we imply that trust - a prerequisite for POM (and in the Norwegian model) - is essential for successful long-term inclusion processes.

Trust is a missing link in COM-dominated workplaces. Annual Norwegian representative survey studies have shown that conflicts and conflict escalation at work are a more dominant feature of COM-organizations than POM-organizations. In addition, there are indications that conflict management takes on another form and is considerably more time consuming in COM than in POM (Enehaug \& Nordrik 2018; Falkum \& Drange 2018; Falkum et al. 2016, 2017, 2018). In addition, work inclusion research has shown that vertical conflicts; tensions and conflicts between newly hired people with reduced ability to work and colleagues, as well as horizontal conflicts between managers and employees, often arise. These conflicts are often related to challenging behavior of the new employees, communication difficulties, the need for extra facilitation, as well as challenges related to inclusion in the psychosocial work environment (Frøyland 2018; Spjelkavik 2019; Stacy et al., 2017; Vornholt et al. 2018; West et al. 2015).

Based on these theoretical perspectives, we hypothesize that workplace inclusion competence and organizational management-orientation are mutually dependent variables and that they may have an effect on each other. The following figure illustrates the relation between organizational management orientation and workplace inclusion competence.

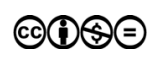


Figure I Organizational management orientation and workplace inclusion competence.

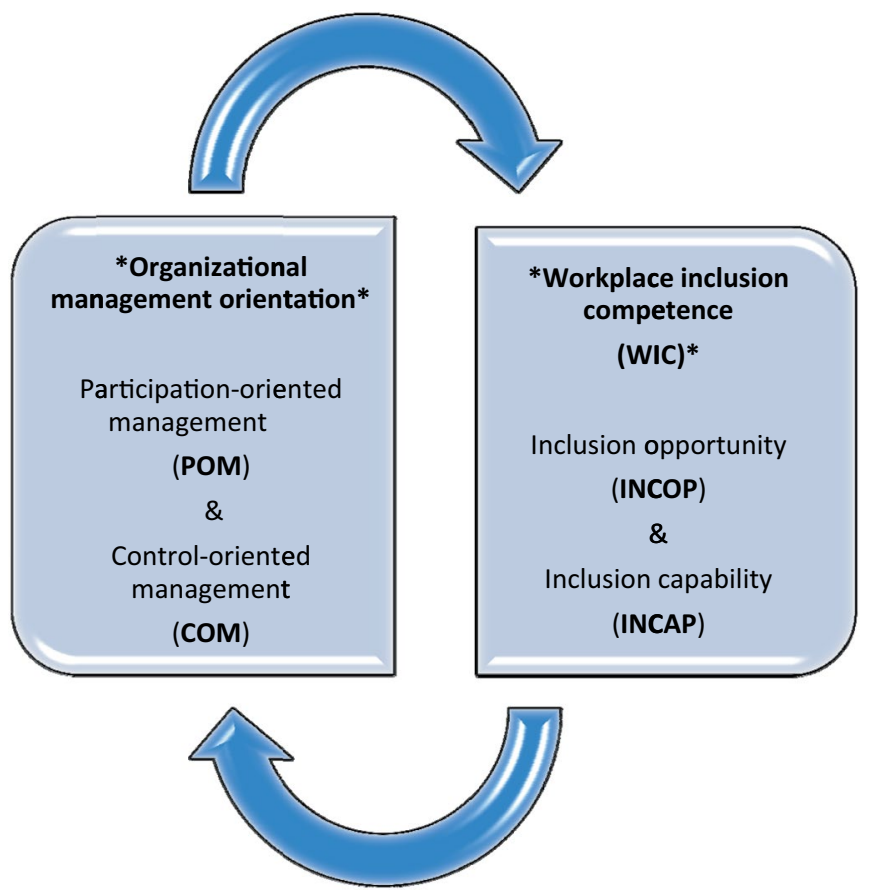

\section{Data, methods and analytical approach}

In order to illustrate and explore the relevance of our theoretical assumptions and hypothesis described above, we draw on empirical data gathered from an annual survey among members of a Norwegian union for managers focusing in particular at the workplace level and activities.

The survey was distributed digitally to approximately 12,000 active members (pensioners are not included). In the survey, the response rate was $19 \%(\mathrm{~N}=2253)$. Sixty-one percent were men and $39 \%$ women. There was an overrepresentation of respondents in the age group 41-50 (34\%) and 51-60 (39\%), but given the fact that the respondents were managers, we consider them representative for this specific population with regard to age. Sixty percent of the respondents had higher education and $40 \%$ have primary or high school as their highest completed education.

The respondents were all managers but represented a range of different job categories, such as lower managers/technicians, operational managers, shift managers, HR managers, advisors, department store managers, team leaders and managing directors. The respondents also represented several industries such as IT, electrical engineering and energy, shipping and oil \& gas supply industry, process industry, mechanical/ other industry, food, fishing and aquaculture, aviation, tourism and transport, building and construction, service, kindergarten, trade, work and inclusion, as well as other industries. 
Most of the respondents worked in the private sector. Almost one out of four are employed in the Oil and gas industry. Eighteen percent work in kindergarten and labor market enterprises, in both public and private businesses.

\section{Analytical approach}

Based on a selection of some of these questions from the survey, we constructed (see Table 1) indexes for control-oriented management (COM) and participation-oriented management (POM). We also constructed of a set of indexes for inclusion capability (INCAP) and inclusion opportunity (INCOP) (see Table 3). The INCAP and INCOP indexes serve as operationalization of workplace inclusion competence at the workplace, for survey use and measurement. The indexes were built up by testing the statistical relationships between questions using factor analysis and reliability tests. Based on these tests, we pooled questions into the two sets of analytical indexes: managementorientation and inclusion skills competence.

\section{Organizational management-orientation}

We divided management theories and models in use in two: (1) based on control of employees, attitudes and behavior, and (2) based on employees' motivation, participation, involvement and contributions in the business, that is a relationship- and participation-based orientation.

We established a distinction between COM and POM in two ways: Firstly, based on the theoretical concepts, we extracted relevant questions in the survey. Secondly, we tested statistically whether they measure different sides of POM and COM, which then would qualify for putting the differing measures together in indexes.

The POM \& COM-indexes consists of the following four questions: To what extent is it important to:

Table I Participation-oriented and control-oriented regimes, index questions

\begin{tabular}{ll}
\hline POM & COM \\
\hline$\ldots$ facilitate good work processes & $\ldots$ control employee attitudes \\
\hline$\ldots$ help develop and motivate employees & $\ldots$ control employee behavior \\
\hline$\ldots$ support employees who 'struggle' & $\ldots$ measure deviations from individual goals / standards \\
\hline$\ldots$ focus on working environment & ... report nonconformities \\
\hline
\end{tabular}

\section{Workplace inclusion competence (WIC)}

The respondents answered specific questions about work inclusion at their own workplaces. We found a divide between the six questions $(3+3)$ listed above. We used this distinction to construct a set of indexes for inclusion opportunity and inclusion capability in the workplace: 
Table 2 Inclusion opportunity and capability, index questions

\begin{tabular}{ll}
\hline Inclusion opportunity (INCOP) & Inclusion capability (INCAP) \\
\hline $\begin{array}{l}\text { To what extent does your business have work } \\
\text { tasks that suit people with reduced work capacity? }\end{array}$ & $\begin{array}{l}\text { To what extent did your business succeed in } \\
\text { including the employee (s) in the social work } \\
\text { environment? }\end{array}$ \\
\hline $\begin{array}{l}\text { To what extent does your business have } \\
\text { opportunities to follow up people with a great } \\
\text { need for facilitation and follow-up? }\end{array}$ & $\begin{array}{l}\text { To what extent did your business succeed in } \\
\text { facilitating work assignments? }\end{array}$ \\
\hline $\begin{array}{l}\text { To what extent does your company have } \\
\text { resources that specifically work on facilitation } \\
\text { and follow-up? }\end{array}$ & $\begin{array}{l}\text { To what extent did your business succeed in } \\
\text { providing the follow-up the employee needed? }\end{array}$ \\
\hline
\end{tabular}

All the questions had five response categories that made up a scale from $1=$ very little to 5 = very much.

The INCOP-index describe different aspects of the company's opportunities to include people with reduced ability to work. The INCAP-index questions were based only of those respondents who confirmed that they had recruited citizens with reduced work ability the last year. In this way, we were able to distinguish between actual inclusion experience (read skills) and the assessment/perception among the managers of their possibility to include.

In order to gain knowledge about the possible role of also other organizational factors, we included in our analysis work pace, developmental opportunities, occupational safety and health (OSH), and the 'economically sound work place' in the organizational analysis based on the assumption that they also affect workplaces' inclusion capabilities (INCAP) and inclusion opportunities (INCOP).

\section{Strengths and limitations}

By combining findings and theoretical perspectives from different streams of literature such as ALMP, work inclusion, management and work environment studies, a major strength of this paper is that it adds to the knowledge about the employer's role in ALMP by developing a new perspective on work inclusion in which organizational management-orientation play an important role. Our empirical analysis of a survey among business managers support these perspectives. This paper also presents two new sets of indexes to measure organizational management-orientation and inclusion skills competence. As such, we contribute to the research field by providing new and more specific concepts with adherent question indexes, and by connecting them to a workorganizational perspective.

There are two main limitations to the empirical data. First, there are no lists of distributions of general characteristics such as age, gender and education in the membership register of the management organization in this survey. We are thus unable to do accurate dropout analyses that show bias in the sample compared to the population. On the other hand, we have more than 2250 responses in general and this constitutes answers from about one fifth of the population. 
Second, industry breakdowns may be problematic in surveys because there are many of them, and because they are defined and sorted differently by industry association. Standard NACE codes have been developed where parent areas with multiple subcategories create a relatively fine mesh. This is used, for example, by Statistics Norway (Statistics Norway). In member surveys, these overall categorizations will be insufficient because the members often have a relatively similar professional background and work in a smaller number of industries. At the same time, it is desirable to be able to compare members in different industries with each other. In this survey, we therefore used more finely masked industry classifications than in the national NACE codes for industries.

\section{Results and discussion}

\section{POM versus COM}

The average score on POM was 4.8 on the scale of $1-5$, which is very high. ${ }^{1}$ The distribution of the index values is skew in favor of high scores on participation. This means that the respondents strongly support the ideas of participation in the Norwegian work life model the way it is measured in our studies. The reliability test, however, shows that the four questions (Table 2) measure different aspects of the same phenomenon (Cronbach's alpha $=0,82)$. We merged them into the index for participation-oriented management.

COM also have a high average score, 3.7, even if it is lower than the scores on POM. Other studies have shown that the prevalence of control-oriented governance and management models has increased in the Norwegian work life since the 1980s (Falkum 2020). Reliability testing of our survey data showed a sufficiently large internal relationship between the questions which constitute the COM index (Cronbach's alpha = 0.78).

COM describe a managerial focus on employee control, attitude and behavior, versus a POM managerial focus on employee motivation, participation, involvement and contribution to the business, that is individually focused and participation-oriented management. We emphasize that these are not absolute categories/distinctions between different forms of work organization; these indexes indicate what type of managementorientation is most dominant (Drange et al. 2020).

Thus, the two categories are not mutually exclusive. You might have a high degree of POM combined with a high degree of COM. However, the statistical correlations between control oriented and participation-oriented governance and management systems in general are usually negative. In the Co-determination survey studies (20162020) and in an annual management survey (2015-2019) (AUTHORS), a high degree of one of them are normally followed with a low degree on the other index. In this study, COM and POM have a slightly positive correlation $\left(\mathrm{r}=0.23^{* *}\right)$. As control-oriented managerial systems spread, the correlation with participation oriented managerial systems might be even stronger (Falkum 2020).

\section{Workplace inclusion competence}

A factor analysis confirmed that INCOP-questions have a high statistical correlation with each other and constitute a separate factor that charges the data set in the same 
direction (See Rotated component varimax in appendix). Similarly, the INCAP-questions constitute a separate factor that charges the data set in a different direction from the first. We used a reliability test to measure the internal correlation between the variables and check whether the variables could be merged into an index. We found that the Cronbach's alpha $=0.827$ for INCOP, and 0.755 for INCAP. Both relationships are significant at the 0.001 level.

\section{Inclusion opportunity (INCOP) and actual inclusion}

The total percentage of businesses that score their inclusion opportunity as high or very high is $38 \%$. There is a high degree of variation between the industries regarding inclusion experiences. Table 4 shows the score for inclusion opportunities and actual inclusion during last year across the various industries in the survey.

Table 4 Inclusion opportunity and actual inclusion

\begin{tabular}{lcccc}
\hline \multirow{2}{*}{ Type of industry } & \multicolumn{2}{c}{ Inclusion opportunity } & \multicolumn{2}{c}{ Inclusion last year } \\
\cline { 2 - 5 } & $\mathbf{\%}$ & $\mathbf{N}$ & $\%$ & $\mathbf{N}$ \\
\hline IT, electrical engineering and energy & $\mathbf{1 8}$ & 39 & $\mathbf{9}$ & $(44)$ \\
\hline Shipping and oil \& gas supply industry & $\mathbf{1 5}$ & 20 & $\mathbf{1 7}$ & $(23)$ \\
\hline Oil and gas & $\mathbf{1 9}$ & 149 & $\mathbf{2 2}$ & $(180)$ \\
\hline Process industry & $\mathbf{2 1}$ & 54 & $\mathbf{2 8}$ & $(57)$ \\
\hline Mechanical/other industry & $\mathbf{1 4}$ & 48 & $\mathbf{2 8}$ & $(51)$ \\
\hline Food, fishing and aquaculture & $\mathbf{1 5}$ & 54 & $\mathbf{3 1}$ & $(58)$ \\
\hline Aviation, tourism and transport & $\mathbf{1 2}$ & 34 & $\mathbf{3 2}$ & $(40)$ \\
\hline Building and construction & $\mathbf{2 1}$ & 47 & $\mathbf{3 3}$ & $(51)$ \\
\hline Other & $\mathbf{1 6}$ & 227 & $\mathbf{3 5}$ & $(239)$ \\
\hline Service & $\mathbf{1 4}$ & 118 & $\mathbf{4 3}$ & $(127)$ \\
\hline Kindergarten & $\mathbf{1 8}$ & 194 & $\mathbf{4 6}$ & $(196)$ \\
\hline Trade & $\mathbf{2 2}$ & 178 & $\mathbf{4 8}$ & $(192)$ \\
\hline Work and inclusion & $\mathbf{7 2}$ & 76 & $\mathbf{7 3}$ & $(77)$ \\
\hline
\end{tabular}

Column 2-3: Percentage who believe the opportunities for inclusion are good (scores high on the inclusion opportunity index). Column 4-5: Over the past 12 months, have you included people with reduced work capacity? Breakdown by industry (percentage answering yes, $N=1335$ ).

We find a high degree of variation between the industries with regard to inclusion experiences, between $9 \%$ and $73 \%$ report actual inclusion of people with reduced work capacity over the past 12 months. Although previous studies have shown that kindergartens and the retail trade are widely used industries for work inclusion efforts (Jensen \& Nergaard 2017; Nicolaisen 2017), our data also indicates that inclusion actually takes place in a variety of industries. This is in line with Spjelkavik et al. (2020), who find that a broad range of industries and companies are involved in work inclusion efforts 
at different levels and with various degrees of engagement. However, with the exception of the industry categorization IT, electrical engineering and energy, all of the industries in our study have a substantially lower assessment of inclusion opportunities than actual inclusion last year. These industries seem to do more actual inclusion than they assess as possible. We interpret this as an argument against relying solely on employer engagement.

Moreover, we find it interesting that both the retail trade and the service industries have high scores on actual inclusion $(48 \%$ and $43 \%)$ but considerably lower on INCOP (22 versus 14). We wonder if this is caused by a high need for (cheap) temporary labor, but lack of opportunities or employ people with reduced work abilities due to risk anticipations? Previous studies show that there are certain industry differences related to the type and requirements of work tasks. For example, the retail trade is a widely used industry for work experience placements because of the availability of easy access job tasks and low formal demands (Nicolaisen 2017; Sørensen 2003). A Danish study (Jakobsen et al. 2015) showed that employers' positive experiences, combined with actual labor needs, were important factors for considering hiring people with reduced work ability. Employers in companies that already employed citizens with reduced work ability, more often than others, were positive to hire (more) citizens in the same category. In this study, employers stated that public financial support for hiring people with reduced work ability makes a difference. Put another way; some businesses may initially have better opportunities for initiating work inclusion than others, while others need additional risk reducing support. Even so, according to Jacobsen and colleagues, lack of financial support could not explain why some employers did not employ in the first place. The main reasons are uncertainty as to whether people with reduced work ability have necessary qualifications, can perform well enough, and need any extra followup. Norwegian research finds similar traits; previous experience with work inclusion makes employers less likely to view inclusion as risky (Falkum \& Solberg 2015; Svalund $\&$ Hansen 2013). In addition, managers with knowledge about vulnerable citizens are more willing to employ these groups than other managers (Lauveng 2008; Schafft 2013, 2014).

In Table 4, we also see that work and inclusion businesses stand out clearly. This is not surprising, as they are providers of ALMP measures and thus aimed at contributing to the inclusion of vulnerable groups. These managers probably correspond with Bredgaard's category of committed employers, but they represent a very distinctive and deviant industry where it is reasonable to expect positive attitudes to inclusion. Because of this, we have chosen to exclude them from the following analysis, except in the figures where the work and inclusion businesses appear as a separate category.

\section{Inclusion capability (INCAP)}

As shown in Table 5, the respondents assess their companies' inclusion capability as good. The scores indicate that they believe they succeeded in their inclusion efforts. However, it is important to note that the figures for some of the sectors are very low and that the results do not necessarily reflect absolute differences, but rather give indications of a direction.

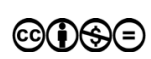


Table 5 Inclusion capability by index variables

\begin{tabular}{|c|c|c|c|c|c|c|}
\hline $\begin{array}{l}\text { To what extent did your } \\
\text { business succeed in ... }\end{array}$ & $\begin{array}{l}\text { Very low } \\
\text { degree }\end{array}$ & 2 & 3 & 4 & $\begin{array}{l}\text { Very high } \\
\text { degree }\end{array}$ & $\begin{array}{l}\text { Do not } \\
\text { know }\end{array}$ \\
\hline $\begin{array}{l}\text {... providing the follow-up the } \\
\text { employee needed? }\end{array}$ & I & 4 & 21 & 45 & 28 & 2 \\
\hline ... facilitating work assignments? & I & 4 & 15 & 41 & 38 & 1 \\
\hline $\begin{array}{l}\text {... including the employee (s) in the } \\
\text { psychosocial work environment? }\end{array}$ & I & 3 & 17 & 33 & 44 & 2 \\
\hline
\end{tabular}

Percentage $(N=500)$

Table 5 shows the score for the three variables in the inclusion capability index separately. Close to $80 \%$ of the respondents rate the facilitation of work assignments and inclusion in the psychosocial work environment a success - and that providing the necessary follow-up is the most difficult part of the inclusion effort.

In addition, our analysis shows that about $38 \%$ of the respondents who, during the past 12 months, have included citizens with reduced work ability, mainly made positive assessments of INCAP. As such, these companies may correspond to Bredgaard's category engaged employers; they have positive attitudes and they are doing active efforts in work inclusion.

\section{In-house inclusion resources}

Our analysis shows that it is relatively uncommon to dedicate specific functions within the company the responsibilities for facilitation and follow-up of people with reduced work ability. When asked the question 'To what extent does your company have resources that work specifically with facilitation and follow-up?' Sixty-two percent of the respondents answered low/very low degree and 18\% answered high/very high degree.

In general, research has showed that small and medium sized enterprises often have less resources or personnel with specific tasks related to training, facilitation and followup than larger companies, which have professional HR departments (Nyamubarwa \& Chipunza 2019; Psychogios et al. 2016). However, this cannot explain our finding that only four out 10 have dedicated resources for follow-up and facilitation. Many of the respondents of this survey work in large companies that may have professional HR departments. Our findings therefore suggest that even large companies do not allocate specific resources or attention to inclusion processes. The numbers also indicate that the managers see very limited possibilities to facilitate work inclusion for people with reduced work ability. Most of these managers possibly fit into Bredgaard's category 'passive employers', as they are positively attuned, but see few possibilities, and make few active efforts. This makes it important to develop more knowledge about management-orientation and other work environment factors for inclusion opportunities and capability. 


\section{Management-orientation in association with inclusion opportunities and - capabilities}

Table 6 shows the statistical relationships between the two types of organizational management-orientation and perceived inclusion opportunity and inclusion capability. Our analysis shows a weak positive and statistically significant relationship $\left(\mathrm{p}=0.19^{* * *}\right)$ between POM and INCAP. This means that a form of management that is focused both on results and development, support, facilitation and work environment factors may provide good conditions for success in inclusion. POM has also proven fruitful as a way to facilitate organizational learning and increased productivity (Enehaug 2017) - and to prevent or manage workplace conflicts in a constructive way (Enehaug \& Nordrik 2018).

Table 6 Statistical relationships between management-orientation and perceived inclusion opportunity and capability

\begin{tabular}{lcccc}
\hline & POM & COM & INCOP & INCAP \\
\hline POM & I & & & \\
\hline COM & $0,23^{* *}$ & 1 & & \\
\hline INCOP & 0,04 & $0,06^{*}$ & 1 & 1 \\
\hline INCAP & $0,19^{* *}$ & 0,07 & $0,47^{* *}$ & \\
\hline
\end{tabular}

We also find a moderate to strong positive correlation between inclusion capability and inclusion opportunity. That is, those respondents who report having a high degree of inclusion opportunity also include citizens with reduced work ability in practice. This indicates that management-orientation is of great importance in the inclusion of people with reduced work ability.

Additionally, we find a somewhat weak, but positive and significant correlation, between COM and POM. This suggests that it is difficult to identify and measure pure management-orientation models that are used in the same way everywhere. On the contrary, management concepts and models are 'translated', interpreted and applied in various ways in order to match with organizational contexts specific for each enterprise and workplace (Røvik 1998, 2007).

We find only insignificant correlations between COM and WIC. Thirty-five percent of POM have a very high degree of WIC (scores five on both scales INCOP/INCAP). Overall, POM provide good conditions for WIC, while COM does not correlate significantly with either INCOP or INCAP.

\section{Associations between inclusion opportunities and capabilities - an extended perspective}

In order to check out the possible impact of other factors, we added selected work environment factors (for elaboration, see section Theoretical perspectives) to the analysis. Table 7 shows moderate positive statistical correlations between INCAP and INCOP $(\mathrm{r}=0.41)$. This indicates that the more experience employers have with inclusion processes, the lower they seem to assess the risk of doing it again. 
Second, INCAP and INCOP both correlate weak, but significantly with the perceptions of the selected work environment factors, and with perceptions of OSH and economically sound workplaces (** significant at 0.01 level). We find that INCAP correlate stronger with positive organizational and economic performance than INCOP.

Table 7 Factors in work organizing, inclusion opportunity and inclusion capability

\begin{tabular}{lcc}
\hline & $\begin{array}{c}\text { Inclusion } \\
\text { opportunity }\end{array}$ & $\begin{array}{c}\text { Inclusion } \\
\text { capability }\end{array}$ \\
\hline Inclusion opportunity & $\mid$ & $\mid$ \\
\hline Inclusion capability & $0.41^{* *}$ & 0.2 I** $^{*}$ \\
\hline Safe and secure workplace (OSH) & $0.14^{* * *}$ & $0.22^{* * *}$ \\
\hline Economically sound workplace & $0.15^{* * *}$ & $0.28^{* * *}$ \\
\hline The employees have good developmental opportunities & $0.20^{* *}$ & $0.27^{* * *}$ \\
\hline Satisfactory pace of work & $0.13^{* * *}$ & \\
\hline
\end{tabular}

Table 7 also show that there is a clear, but weak, connection between experiencing the workplace as safe and secure (OSH) and both the INCOP $(0.14$, very weak) and INCAP $(0.21$, weak). The same applies to the experience of having an economically sound workplace and both forms of inclusion. Our findings thereby indicate that economically sound businesses do better on WIC than those that do poorly financially. On the other hand, other empirical studies have provided examples of the fact that small businesses in a less favorable financial situation can benefit from hiring employees with special needs who come in with financial support schemes from PES. In such cases, employers might consider support schemes an additional financial resource (Spjelkavik et al. 2020).

We carried out a regression analysis in which we checked for which of the four variables that was the strongest for inclusion capability and inclusion opportunity. This analysis provided a basis for the conclusions about the significance of the various organizational features. The analysis showed that INCAP is positively related to employee development opportunities (0.28, moderate association) and satisfactory work pace (0.27, moderate association). All the correlations are statistically significant. A significant proportion of managers include citizens with reduced work ability and they largely feel that they have succeeded in doing so.

\section{Concluding remarks}

Our aim for this paper was to present a first draft of an interdisciplinary perspective of workplace inclusion based on theories in the fields of work inclusion, work environment and management, with adherent survey questions and indexes. We therefore introduced and operationalized the term workplace inclusion competence (WIC) and analyzed its association to two distinct organizational-level categories; participation-and control-oriented management (POM and COM). We operationalized WIC as inclusion opportunity (INCOP) and inclusion capability (INCAP). We argued that organizational 
management-orientation, as well as other work environmental factors (work pace, employees' developmental opportunities, financial situation and $\mathrm{OSH}$ ), have an impact on the development of WIC.

Our findings contribute to the research field of work inclusion by providing new and more specific concepts with adherent question indexes, and by connecting these concepts to a work-organizational perspective. We have argued that it is not sufficient to identify and chart employer engagement (Bredgaard 2017). Attitudes and engagement reflect a number of factors; for example, the presence of stereotypes in work organizations due to previous experiences or lessons learned from earlier collaboration with PES (Gustafsson et al. 2013c; van Berkel et al. 2017b).

Our initial assumptions, that there is an association between management-orientation and the ability to develop and practice WIC is supported by our findings. This finding is partially in line with a study of managers' hiring intentions and the actual hiring of qualified workers with disabilities. Araten-Bergman (2016:1525) recommends that 'efforts must be expanded to influence the organizational senior management to develop and implement explicit disability related diversity policies, and to help design innovative inclusive recruitment processes'.

In our study, only one out of four managers had work inclusion experiences last year. These managers also assessed their own inclusion capability (INCAP-index) in a positive manner. We also found that the majority of managers (eight out of ten) scored high regarding opportunities for inclusion (INCOP-index). As more managers assess their workplaces' inclusion opportunities higher than their actual inclusion, this indicates that there might be an underutilization of workplaces' opportunities in work inclusion and that the more experience employers have with inclusion processes, the more positively they assess their possibilities. This is also in line with the reasoning for the concept of experience-based WIC-development. We are hesitant about assuming causal relationships in our correlation analysis, but we find support in other research that actual work inclusion experience seems to lower the threshold for inclusion of citizens with reduced work ability (Falkum \& Solberg 2015; Jakobsen et al. 2015), and that the potential for work inclusion is larger than among employers initially regarded as engaged (cf. Bredgaard 2017).

We found that INCAP is positively related to employee development opportunities and a satisfactory work pace. This corresponds to Bredgaard's (2017) engaged employers-perspective, but situated within the work organizational context. A satisfactory work pace implies that the demands of the job and the resources necessary to do the job are in balance. Furthermore, workplaces that provide development opportunities for employees are likely to have a flexible approach to the organization of work and to view employees' competencies and skills not as fixed entities. For people with reduced work ability, mastery in work may demand more customization, time resources and general effort from the work organization in order to balance the needs of the individual and the organization. A possible hypothesis for future research based on these findings is to examine whether businesses with a POM-organization are better suited to include people with reduced work ability. In a POM environment, the work organization is oriented towards flexible solutions of work tasks and constant employee development.

POM contributes to workplace learning which is essential for the development of WIC. A possible implication of this is that working towards WIC may contribute 
to the development of POM, and the other way around. POM may contribute to the development of WIC - they both have a common ground; focus on individual and organizational learning and development. To conclude, we find partial support for the initial assumptions that POM provides better inclusion opportunities than COM. Even so, considering that the proportion of respondents who describe their own work organization as mainly dominated by COM is lower than those who fall into the POM, we cannot state this as a fact. However, even if POM is associated with successful inclusion processes, we cannot conclude that COM is not. There is a need to examine this hypothesis in more detail in a larger sample of respondents and preferably in a representative dataset.

The challenge in work inclusion is no longer to make the client job-ready, which was the reasoning behind former supply side measures of ALMP (Andersen et al. 2017; NOU 2012:6; van Berkel et al. 2017a). Within the place-train paradigm, it is just as much about how the workplace can contribute to develop the individuals' work ability and secure job retention. This further implies the necessity of support in order to develop and improve job match quality and the person-environment fit (Kirsh 2000; Kirsh et al. 2009). Seen from PES' point of view, this means that in a COM environment more collaborative efforts must be made to contribute to the development of WIC. It also means that by seeking to identify management orientation, PES may more proactively contribute to the development of WIC, and that the PES approach must differ according to management orientation. This implies expanding the perspectives on PES' matchmaker role (van Berkel et al. 2017b) and employer engagement (Bredgaard 2017), to include an understanding of the organizational context in which work inclusion takes place.

In practical terms, this means that frontline workers in PES cannot assess opportunities and limitations for work inclusion in different companies only as they appear at a distance. Rather they have to get involved in the organizational context where inclusion processes unfold. In other words, the development of ISC and WIC are equally important. WIC and ISC are two different, but mostly interdependent, competencies in inclusion processes. ISC represent frontline workers skilled approach and knowledge of individuals, workplaces and inclusion/exclusion processes, while WIC represent the workplaces' skilled and knowledge-based approach to accommodation in the daily follow-up of employees with reduced work ability. Knowledge development concerning work environment and the organization of work in general may therefore prove to be important for both frontline workers and workplaces in inclusion processes. Indicative findings suggest that closer collaboration in the interface between PES and the workplace helps develop ISC and WIC simultaneously. The workplace learns more about PES, client's challenges and support needs, while PES learns more about the actual challenges in the workplace in work inclusion efforts (Spjelkavik et al. 2020). We therefore assume that the development of ISC and WIC may take place simultaneously; when PES' frontline workers develop ISC, they may affect the development of WIC. As such, ISC influences the role of employers in ALMP. When workplaces develop WIC, they may affect the development of ISC in PES.

If work inclusion takes place in a COM environment, PES's role must be comprehensive in the development of WIC. With this in mind, addressing employers' engagement and social responsibility is not sufficient - more intensive employer support and collaboration between PES and employers is needed. 


\section{References}

Andersen, N. A., Caswell, D., \& Larsen, F. (2017). A New approach to Helping the hard-toplace Unemployed:The promise of developing new knowledge in an interactive and collaborative process, European Journal of Social Security, 19(4), 335-352. doi: https://doi. org/10.1177/1388262717745193.

Araten-Bergman, T. (2016). Managers' hiring intentions and the actual hiring of qualified workers with disabilities, The International Journal of Human Resource Management, 27(14), 1510-1530. doi: https://doi.org/10.1080/09585192.2015.1128466.

Berg, A. M. (1998). Den vanskelige medvirkningen. Arbeidstakermedvirkning i staten 19701996 [The difficult participation. Employee participation in the State 1970-1996] (Vol. 5), Oslo: Arbeidsforskningsinstituttet.

Berge, T., \& Falkum, E. (2013). Se mulighetene. Arbeidsliv og psykisk helse [Look for the possibilities. Work and mental health], Oslo: Gyldendal Akademisk.

Bjørnshagen, V., \& Ugreninov, E. (2021). Labour market inclusion of young people with mental health problems in Norway, Alter, 15(1), 46-60. doi: https://doi.org/10.1016/j.alter. 2020.06 .014$.

Bonfils, I. S., Hansen, H., Dalum, H. S., \& Eplov, L. F. (2017). Implementation of the individual placement and support approach - facilitators and barriers, Scandinavian Journal of Disability Research, 19(4), 318-333. doi: https://doi.org/10.1080/15017419.2016. 1222306.

Bonvin, J.-M., \& Galster, D. (2010). Making them Employable or Capable? Social Integration Policies at a Crossroads. In H.-U. Otto \& H. Ziegler (Eds.), Education, Welfare and the Capabilities Approach. A European Perspective. (pp. 71-83), Opladen \& Farmington Hills: Barbara Budrich Publishers.

Bredgaard, T. (2017). Employers and Active Labour Market Policies: Typologies and Evidence, Social Policy and Society, 1-13. doi: https://doi.org/10.1017/S147474641700015X.

Bredgaard, T., \& Halkjær, J. L. (2016). Employers and the Implementation of Active Labor Market Policies, Nordic Journal of Working Life Studies; Vol 6, No 1 (2016) doi: https:// doi.org/10.19154/njwls.v6i1.4909.

Bredgaard, T., Larsen, F., Høgedahl, L., Ravn, R., Larsen, M. F., Hansen, C., \& Pedersen, M. L. (2015). International komparativ analyse: Ydelsessystemer, reformer og indsatser overfor ikke-arbejdsmarkedsparate borgere i fem lande [International comparative analysis: supportsystems, reforms and effors towards non-employable citizens of five countries], København: Aalborg Universitet.

Drange, I., Falkum, E., \& Wathne, C. T. (2020). Styring, ledelse og tillit. Medbestemmelsesbarometeret 2020 [Governance, leadership and trust. The Co-determination Barometer 2020], Oslo: Arbeidsforskningsinstituttet/OsloMet.

Dølvik, J. E., Fløtten, T., Hernes, G., \& Hippe, J. M. (Eds.). (2007). Hamskifte. Den norske modellen $i$ endring [The Norwegian Model in transition], Oslo: Gyldendal akademisk.

Edwards, K., Bojesen, A., Paarup Nielsen, A., \& (eds.). (2010). Lean og arbejdsmiliø - et dynamisk spoendingsfelt [Lean and work environment - a dynamic field of tension], København: LR BUSINESS Egmont.

Enehaug, H. (2017). Ten Successful Years: A Longitudinal Case Study of Autonomy, Control and Learning, Nordic Journal of working life studies, 7(S2), 67-89. doi: https://doi. org/10.18291/njwls.v7iS2.96693.

Enehaug, H. (2018). Å loere av det gamle, for å forberede seg på det nye. En studie av medvirkningens betydning for organisatorisk utvikling og laering [To learn from the old, to prepare for the new. A study of the significance of participation for organizational development and learning]. (Ph.D), Roskilde University, Roskilde. 
Enehaug, H., Falkum, E., \& Hvid, H. S. (2019). Democracy at work. In Working in the Nordic Countries - a critical perspective on the world's best working life (pp. 49-66), London: Routhledge.

Enehaug, H., \& Nordrik, B. (2018). Konflikter, konflikthåndtering og integritet [Conflicts, conflict management and integrity]. Oslo: Arbeidsforskningsinstiuttet/OsloMet.

Falkum, E. (2020). Makt og opposisjon i arbeidslivet: Maktforskyvninger fra 1900 til 2020 [Power and opposition in working life: Power shifts from 1900 to 2020], Oslo: Cappelen Damm Akademisk.

Falkum, E., \& Drange, I. (2018). Medbestemmelsesbarometeret 2017. Delrapport 2: Bedriftsdemokrati og eierskap [The co-determination barometer 2017. Report 2: Business democracy and ownership], Oslo: Arbeidsforskningsinstituttet/OsloMet.

Falkum, E., Ingelsrud, M. H., \& Nordrik, B. (2016). Medbestemmelsesbarometeret 2016 [The Co-determination barometer 2016] (FOU-resultat 2016:08), Oslo: Arbeidsforskningsinstituttet/OsloMet.

Falkum, E., Nordrik, B., Drange, I., \& Wathne, C. T. (2017). Medbestemmelsesbarometeret 2017: Arbeidslivsrelasjoner $i$ endring [The co-determination barometer 2017: Working life relations in change], Oslo: Arbeidsforskningsinstituttet/OsloMet.

Falkum, E., Nordrik, B., \& Enehaug, H. (2018). Ledelse på norsk. Medvirkning og medbestemmelse - to former for styring og ledelse. Norsk Ledelsesbarometer 10 år [Management in Norwegian. Participation and co-determination - two forms of management], Oslo: Arbeidsforskningsinstituttet/OsloMet.

Falkum, E., Schafft, A., \& Spjelkavik, Ø. (2014). Arbeidsgivernes rolle i inkluderingen [The role of employers in inclusion]. In K. Frøyland \& Ø. Spjelkavik (Eds.), Inkluderingskompetanse. Ordincert arbeid som mål og middel (pp. 142-155), Oslo: Gyldendal Akademisk.

Falkum, E., \& Solberg, A. G. (2015). Arbeidsgiveres inkluderingsevne [Employers inclusion skills] AFI-rapport 5/2015, Oslo: Arbeidsforskningsinstiuttet ved HIOA.

Frøyland, K. (2018). Et inkluderende arbeidsliv: Til glede eller besvær? [An inclusive working life: pleasure or trouble?]. In H. Heen \& R. Salomon (Eds.), Varme konflikter i arbeidslivet. Organisatoriske perspektiver og håndteringsmetoder, Oslo: Gyldendal Akademisk.

Frøyland, K., Schafft, A., \& Spjelkavik, Ø. (2019a). Tackling increasing marginalization: Can support-side approaches contribute to work inclusion? In Work and Wellbeing in the Nordic Countries: Critical Perspectives on the World's Best Working Life, London: Routledge.

Frøyland, K., Schafft, A., \& Spjelkavik, Ø. (2019b). Tackling Increasing Marginalization: Can Support-Side Approaches Contribute to Work Inclusion? In H. Hvid \& E. Falkum (Eds.), Work and Wellbeing in the Nordic Countries, London: Routhledge.

Frøyland, K., \& Spjelkavik, Ø. (2014). Inkluderingskompetanse. Ordincert arbeid som mål og middel [Inclusion Skills Competence. Ordinary work as goal and means], Oslo: Gyldendal Akademisk Forlag AS.

Gardell, B., \& Svensson, L. (1981). Medbestämmande och självstyre - en lokal facklig strategi för demokratisering av arbetsplatsen [Participation and self-government-a local strategy for workplace democratization], Stockholm: Prisma.

Gustafsson, J., Peralta, J., \& Danermark, B. (2013). The employer's perspective: employment of people with disabilities in wage subsidized employments, Scandinavian Journal of Disability Research. doi: http://doi.org/10.1080/15017419.2013.785976.

Gustafsson, J., Peralta, J. P., \& Danermark, B. (2013). The employer's perspective on Supported employment for people with disabilities: Successful approaches of Supported employment organizations, Journal of Vocational Rehabilitation, 38(2), 99-111. doi: https://doi. org/10.3233/JVR-130624.

Gustavsen, B. (2007). Interventions and the Challenge of Learning from Experience (Vol. Lyon). Høgskolen i Vestfold, Fakultet for økonomi og samfunnsvitenskap: ANACT. 
Gustavsen, B. (2011). The Nordic model of work organization, Journal of the Knowledge Economy, 2(4), 463-480. doi: https://doi.org/10.1007/s13132-011-0064-5.

Hardoy, I., Røed, K., Simson, K. v., \& Zhang, T. (2017). Effekter av arbeidsmarkedspolitikk rettet mot ungdom i Nord-Europa - en meta-analyse [Effects of labor market policies aimed at young people in Northern Europe - a meta-analysis], Søkelys på arbeidslivet, 34(03), 167-181. doi: https://doi.org/10.18261/issn.1504-7989-2017-03-02.

Hasle, P., Bojesen, A., Jensen, L. P., \& Bramming, P. (2012). Lean and the working environment: a review of the literature, International Journal of Operations \& Production Management, 32(7), 829-849. doi: http://dx.doi.org/10.1108/01443571211250103.

Hasle, P., \& Sørensen, O. H. (2013). Employees as Individually and Collectively Acting Subjects- Key Contributions from Nordic Working Life Research, Nordic Journal of Working Life Studies, 3(3), 9-28. https://doi.org/10.19154/njwls.v3i3.3009.

Hauss, G. (2014). Generating productive citizens or supporting the weak? Ambivalences and contradictions in working with young welfare recipients, European Journal of Social Work, 17(5), 656-671. doi: https://doi.org/10.1080/13691457.2014.954239.

Holt, H., \& Hvid, H. (2014). Management and employee control in current industrial work, Nordic Journal of Working Life Studies, 4(4), 57-78. doi: https://doi.org/10.19154/njwls. $\mathrm{v} 4 \mathrm{i} 3.4180$.

Hvid, H. (2014). Socioteknik som samfundsforandring [Socio-technology as a societal change]. Tidsskrift for Arbejdsliv. doi: https://doi.org/10.7146/tfa.v16i4.108982.

Hvid, H., \& Falkum, E. (Eds.). (2019). Work and well being in the Nordic countries. Critical perspectives on the world's best working lives, New York/London: Routledge.

Ingold, J., \& Stuart, M. (2015). The Demand-Side of Active Labour Market Policies: A Regional Study of Employer Engagement in the Work Programme, Journal of Social Policy, 44(3), 443-462. doi: https://doi.org/10.1017/S0047279414000890.

Jakobsen, V., Larsen, M., \& Jensen, S. (2015). Virksombeders sociale engagement: Årbog 2015 [Corporate social responsibility: yearbook 2015], København: SFI - Det Nationale forskningscenter for velfærd.

Jensen, R. S., \& Nergaard, K. (2017). Varehandelen som inkluderingsarena. Rekruttering, opplaring og arbeidstrening [The retail trade as an inclusion arena. Recruitment, training and work training], Oslo: Fafo-rapport 2017:25.

Johnsen, H. C. G. (2005). Aksjonsfaget: Fra økonomisk demokrati til kommunikativ vending - et idéhistorisk perspektiv [The Action disipline: From economic democracy to communicative turn - an idea-historical perspective]. In E. Døving \& Å. Johnsen (Eds.), Organisasjonsteori på norsk, Bergen: Fagbokforlaget.

Karasek, R. (1979). Job Demands, job decision latitude, and mental strain: Implications for job redesign, Administrative Science Quarterly, 24(2), 285-308.

Karasek, R. (2004). A Tool for Creating Healthier Workplaces: The Conducivity Process, Bulletin of Science, Technology \& Society, 24(5), 471-479.

Karasek, R., \& Theorell, T. (1990). Healthy work: stress, productivity, and the reconstruction of working life, New York: Basic Books.

Kasvio, A., Gonäs, I. J., \& Skorstad, E. (2012). In search of the Nordic Working Life Model; Introduction to the Thematic Issue, Nordic Journal of working life studies, 2(4), 1-19. doi: https://doi.org/10.19154/njwls.v2i4.2302.

Kinoshita, Y., Furukawa, T. A., Kinoshita, K., Honyashiki, M., Omori, I. M., Marshall, M., ... Kingdon, D. (2013). Supported employment for adults with severe mental illness, The Cochrane Database Of Systematic Reviews(9), CD008297. doi: https://doi. org/10.1002/14651858.CD008297.pub2.

Kirsh, B. (2000). Organizational culture, climate and person-environment fit: Relationships with employment outcomes for mental health consumers, Work, 14(2), 109-122. 
Kirsh, B., Stergiou-Kita, M., Gewurtz, R., Dawson, D., Krupa, T., Lysaght, R., \& Shaw, L. (2009). From margins to mainstream: what do we know about work integration for persons with brain injury, mental illness and intellectual disability? Work, 32(4), 391-405. doi: https://doi.org/10.3233/WOR-2009-0851.

Kuvaas, B. (2008). Prestasjonsbasert belønning og motivasjon [Performance-based reward and motivation]. In A. Dysvik \& B. Kuvaas (Eds.), Lønnsombet giennom menneskelige ressurser. Evidensbasert HRM. Bergen: Fagbokforlaget.

Lauveng, A. (2008). Arbeidsmaur med gipset hjerte [Working ants with plastered hearts], Oslo: Universitetsforlaget.

Murfitt, K., Crosbie, J., Zammit, J., \& Williams, G. (2018). Employer engagement in active labour market programmes: The role of boundary spanners, Journal of Vocational Rehabilitation, 48(3), 417-431. doi: https://doi.org/10.3233/JVR-180949.

Nicolaisen, H. (2017). Inkludering av unge på AAP-et arbeidsgiverperspektiv [Inclusion of young people in AAP - an employer perspective], Arbeid og Velferd, 2, 35-48.

NOU (2012:6). Arbeidsrettede tiltak [Work-oriented measures]. Oslo.

Nyamubarwa, W., \& Chipunza, C. (2019). Debunking the one-size-fits-all approach to human resource management: A review of human resource practices in small and medium-sized enterprise firms, SA Journal of Human Resource Management, 17. doi: https:// doi.org/10.4102/sajhrm.v17i0.1108.

Nylehn, B. (2008). Organisasjonsfaget $i$ Norge. Analyser av et segmentert fagfelt [The organization disipline in Norway. Analysis of a segmented field], Bergen: Fagbokforlaget.

Nøkleby, H., Blaasvær, N., \& Berg, R. (2017). Supported Employment for arbeidssøkere med bistandsbehov: en systematisk oversikt [Supported Employment for jobseekers in need of assistance: a systematic review], Oslo: Folkehelseinstituttet.

Oldham, G. R., \& Hackman, J. R. (2010). Commentary: Not what it was and not what it will be: The future of job design research, Journal of Organizational Behavior, 31, 463-479. doi: https://doi.org/10.1002/job.678.

Parker, S., Van den Broeck, A., \& Holman, D. (2017). Work Design Influences: A Synthesis of Multilevel Factors that Affect the Design of Jobs (Vol. 11). doi: https://doi.org/10.5465/ annals.2014.0054.

Psychogios, A., Szamosi Leslie, T., Prouska, R., \& Brewster, C. (2016). A three-fold framework for understanding HRM practices in South-Eastern European SMEs, Employee Relations, 38(3), 310-331. doi: https://doi.org/10.1108/ER-07-2014-0078.

Reme, S. E., Monstad, K., Fyhn, T., Sveinsdottir, V., Løvvik, C., Lie, S. A., \& Øverland, S. (2019). A randomized controlled multicenter trial of individual placement and support for patients with moderate-to-severe mental illness, Scandinavian Journal of Work, Environment \& Health(1), 33-41. doi: https://doi.org/10.5271/sjweh.3753.

Rolfsen, M. (2014). Lean blir norsk: Lean i den norske samarbeidsmodellen [Lean becomes Norwegian: Lean in the Norwegian collaboration model], Bergen: Fagbokforlaget.

Røvik, K. A. (1998). Moderne organisasjoner: trender $i$ organisasjonstenkningen ved tusenarsskiftet [Modern organizations: trends in organizational thinking at the turn of the millennium], Bergen-Sandviken: Fagbokforlaget.

Røvik, K. A. (2007). Trender og translasjoner. Ideer som former det 21. århundrets organisasjoner [Trends and translations. Ideas that shape 21st century organizations], Oslo: Universitetsforlaget.

Schafft, A. (2013). Om å komme seg i arbeid [About getting in work]. In R. Norvoll (Ed.), Samfunn og psykisk helse. Samfunnsvitenskapelige perspektiver (pp. 188-212), Oslo: Gyldendal Akademisk.

Schafft, A. (2014). Employer guides: Improving job retention for people with mental health issues. Experiences from a Norwegian pilot project, Journal of Vocational Rehabilitation, 41. doi: https://doi.org/10.3233/JVR-140695. 
Spjelkavik, Ø. (2012). Supported employment in Norway and in the other Nordic countries, Journal of Vocational Rehabilitation, 37(3), 163-172. doi: https://doi.org/10.3233/JVR2012-0611.

Spjelkavik, Ø. (2019). Kan sosialarbeidere bidra i arbeidsinkludering?[Can social workers contribute to work inclusion]. In H. Glemmestad \& L. Kleppe (Eds.), Arbeidsinkludering $i$ sosialt arbeid, Oslo: Fagbokforlaget.

Spjelkavik, Ø., Enehaug, H., Klethagen, P., \& Schafft, A. (2020). Hybridmodellen- samskaping for økt inkluderingskompetanse $i$ NAV og i virksombetene [The hybrid model co-creation for increased inclusion competence in NAV and in the companies], Oslo: Arbeidsforskningsinstituttet/OsloMet.

Stacy, M. A., Stefanovics, E., \& Rosenheck, R. (2017). Reasons for job loss among homeless veterans in supported employment, American Journal of Psychiatric Rehabilitation, 20(1), 16-33. doi: http://dx.doi.org/10.1080/15487768.2016.1267049.

Svalund, J., \& Hansen, I. L. S. (2013). Inkludering av personer med nedsatt funksjonsevne $i$ arbeidslivet [Inclusion of people with disabilities in working life], Oslo: Fafo.

Sørensen, B. A. (2003). Det grådige arbeidslivet [The greedy working life]. In A. Roness \& S. B. Matthiesen (Eds.), Utbrent-krevende jobber-gode liv, Oslo: Fagbokforlaget.

Thorsrud, E., \& Emery, F. E. (1970). Mot en ny bedriftsorganisasjon. Eksperimenter i industrielt demokrati. Fra Samarbeidsprosjektet LO/NAF [Towards a new business organization. Experiments in industrial democracy. From the Cooperation project LO / NAF], Oslo: Johan Grundt Tanum Forlag.

van Berkel, R., Caswell, D., Kupka, P., \& Larsen, F. (2017). Frontline Delivery of Welfare-toWork Policies in Europe: Activating the Unemployed, London: Routhledge.

van Berkel, R., Ingold, J., McGurk, P., Boselie, P., \& Bredgaard, T. (2017). Editorial introduction: An introduction to employer engagement in the field of HRM. Blending social policy and HRM research in promoting vulnerable groups' labour market participation, Human Resource Management Journal, 27(4), 503-513. doi: https://doi.org/10.1111/ 1748-8583.12169.

Villotti, P., Corbière, M., Fossey, E., Fraccaroli, F., Lecomte, T., \& Harvey, C. (2017). Work Accommodations and Natural Supports for Employees with Severe Mental Illness in Social Businesses: An International Comparison, Community Mental Health Journal, 53(7), 864-870. doi: https://doi.org/10.1007/s10597-016-0068-5.

Vornholt, K., Villotti, P., Muschalla, B., Bauer, J., Colella, A., Zijlstra, F., Corbière, M. (2018). Disability and employment - overview and highlights, European Journal of Work and Organizational Psychology, 27(1), 40-55. doi: https://doi.org/10.1080/ 1359432X.2017.1387536.

West, M., Targett, P., Wehman, P., Cifu, G., \& Davis, J. (2015). Separation from supported employment: a retrospective chart review study, Disability and Rehabilitation, 37(12), 1055-1059. doi: https://doi.org/10.3109/09638288.2014.955133.

Womack, J. P., \& Jones, D. T. (1994). From Lean Production to the Lean Enterprise, Harvard Business Review (0), 93-103.

\section{Note}

${ }_{1}^{1}$ The respondents were asked to tick off on a scale from $1=$ very important to $5=$ very important. 


\section{Appendix}

Rotated Component Matrix

\begin{tabular}{lcc}
\hline Now follows some questions about your company's & \multicolumn{2}{c}{ Component } \\
\cline { 2 - 3 } $\begin{array}{l}\text { inclusion opportunities towards people with reduced } \\
\text { work capacity. }\end{array}$ & I = INCOP & $\mathbf{2}$ = INCAP \\
\hline To what extent does your business: have work tasks that fit &, 746 &, 322 \\
\hline $\begin{array}{l}\text { To what extent does your business succeed in: including the } \\
\text { employee(s) in the social work environment }\end{array}$ &, 053 &, 789 \\
\hline $\begin{array}{l}\text { To what extent does your business succeed in: providing the follow-up } \\
\text { that was needed }\end{array}$ &, 283 &, 778 \\
\hline To what extent does your business succeed in: facilitating work tasks &, 270 &, 800 \\
\hline $\begin{array}{l}\text { To what extent does your business have: opportunities to follow up } \\
\text { people with a large need for facilitation and follow-up }\end{array}$ &, 850 &, 213 \\
\hline $\begin{array}{l}\text { To what extent does your business have: resources who work } \\
\text { specifically with facilitation and follow-up }\end{array}$ &, 850 &, 083 \\
\hline
\end{tabular}

Extraction Method: Principal Component Analysis.

Rotation Method:Varimax with Kaiser Normalization.

aRotation converged in 3 iterations. 